\title{
Determining Route of Distribution to Minimize Transportation Costs Using Saving Matrix Method in PT. X
}

\author{
Muhammad $^{1}$, Cut Ita Erliana ${ }^{1}$ and Romi M Sitompul ${ }^{1}$ \\ \{irmuhammad@unimal.ac.id\} \\ ${ }^{1}$ Department of Industrial Engineering, Universitas Malikussaleh, Aceh, Indonesia
}

\begin{abstract}
This study aims to determine the distribution route of goods that can minimize transportation costs in PT.X. Methodology of problem solving approach in this research is saving cost matrix method. This study provides alternative route of distribution that must be passed by as many as 12 routes with $505.08 \mathrm{~km}$ distance, and total transportation cost IDR 15.434.394, while the previous transportation cost is IDR 18.138.897, - per distribution cycle, resulting in cost savings transportation of IDR 2,704,503, or $14.9 \%$ cost savings per distribution cycle.Distribution areas under study include the area of North Sumatra with several sub distributors to Medan, Kabanjahe, Tebing Tinggi, Pematang Siantar, Indrapura, Rantau Prapat, Kisaran, Padang Sidempuan, Balige and Sibolga which are then distributed to foodstore (super market and mini market) and traditional outlets (wholesale).
\end{abstract}

Keywords: Distribution, Transportation, Minimum Cost, Saving Cost Matrix.

\section{Introduction}

Good distribution and transportation is essential for a company so that a product can be delivered to customers on time, in exact quantity, to the place and goods specified in good condition. In general, distribution can be integreted as a marketing activity that aims to facilitate or facilitate the process of delivering goods and services from producers to the hands of consumers, as needed [1]. Every company wants a minimum cost for this transportation process that can provide an optimal solution.

These issues require companies to define an appropriate distribution strategy. One strategy that can be used by customers in the right amount, good condition, in accordance with the promised time, and low transportation costs so as to optimize the use of capacity and number of vehicles. PT. $\mathrm{X}$ is one of the companies that produce beverages in Medan, packaging more responsive to retailers' demand that causes transportation routes to change and less consider the suitability of transportation capacity. With such distribution, the condition of transportation cost requirement is not small. In this study, this study aims to determine the optimal distribution route by considering the transportation capacity by Saving Matrix Method. 


\section{Literature Review}

\subsection{Distribution}

Distribution is an activity to move products from suppliers to consumers in the form of a product. Distribution is a key benefit to the company because the distribution will directly affect the cost of the product and consumer needs, the appropriate distribution network can be used to achieve a variety of product needs ranging from low cost and high response to consumer demand. Distribution term is the same as place (placement) that is activity of channeling or placing of product (goods) from producer to consumer. Material movement occurs in all cycles of the product manufacturing process, either before or after the production process [2].

\subsection{Transportation}

According to Nasution (2004) in [3], transportation is defined as the movement of goods and people from the place of origin to the destination. The transport process is a movement from the place of origin, from where the initial transit activity begins and the destination is an activity where the transport is terminated.

\subsection{Distribution and Transportation Functions}

Traditionally we recognize distribution and transport management with various designations. Some companies use the term logistics management, some companies use the term physical distribution. Whatever the term, in general the function of distribution and transportation is basically delivering the product from the location where the product is produced until the service to the consumer as well as the satisfactory seller's service [3].

\subsection{Transportation Model}

Taha (1996) in [4] suggests that in a simple sense, the transport model seeks to determine a plan of transporting an item from a number of sources to a number of destinations. The data in this model includes: 1 . Offer level in each source and number of requests in each destination. 2. Transportation costs per unit of goods from each source to each destination. Noer (2010) argues that the method of transportation is intended to find the best solution of the problem of transportation (transport) goods or products from warehouses or factories to the destination market with the cheapest cost. Once transport costs have been identified from factory to market, as well as factory capacity and market demand are known then the question of how the best allocation can be done [5].

\subsection{Transportation Issues}

Agustini and Rahmadi (2004) in [6] suggested that transportation cases arise when trying to determine how to transport (distributing) a kind of item from multiple sources (location of offer) to multiple destinations (request locations) that can minimize costs. Usually the amount of goods that can be distributed from each bidding location is fixed or limited, but the number of requests at each request location is varied.

\subsection{Transhipment Model}


Trasnshipment model is a model that allows indirect delivery of goods, in which the goods transported must undergo two or more means of transport, either from a source to another source or other before reaching its final destination. Thus, in this Transhipment Model, a source can simultaneously serve as a goal and vice versa, a goal may also serve as a source. For example, for example, a farmer can not obtain fertilizer from the factory directly, but must go through a regional agent, even the regional agent must go through a new center agent from the factory [7]. The standard transport model assumes that the direct route between a source and a destination is a minimum cost route, by providing the closest route between source and destination. This means that a preparatory calculation involving the determination of the nearest route must be made before the unit cost of the standard transport model can be determined. This calculation can be done by applying the closest route algorithm to the desired node pair. The transhipment model has an additional feature that allows units to be sent from all sources to pass between intermediate and temporary nodes before arriving at destination. As a result, this transhipment model combines both the usual transport algorithm model with the closest route algorithm into a single procedure [8]. Diagrammatically the transhipment model can be seen in Figure 1 below:

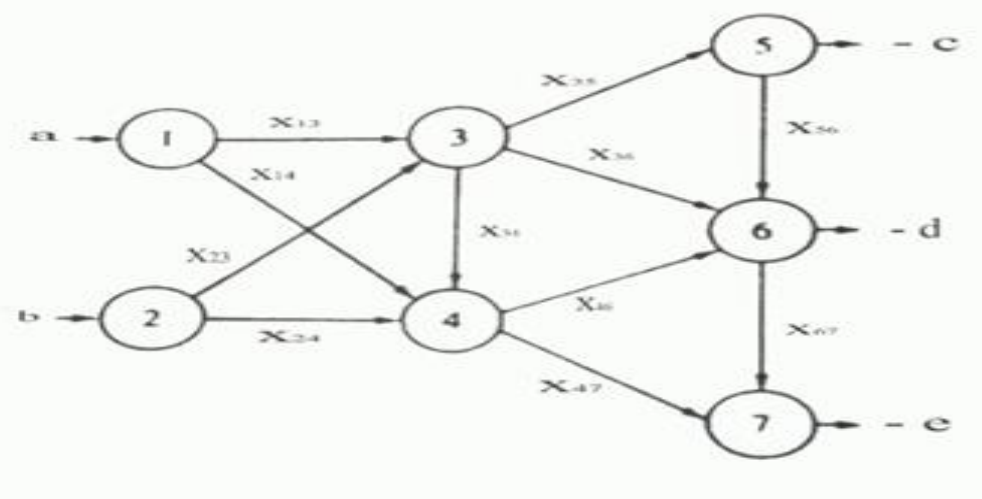

Figure 1. Transhipment models

\subsection{Saving Matrix}

Saving matrix is a method to minimize distance, time or cost by considering the constraints that exist. In the Saving Matrix method there are steps to be taken, the step is to identify the Distance Matrix, identify the Saving Matrix, allocate the retailer to the vehicle or route, sort the retailer (destination) in a predefined route. In steps one through three are used for the determination of vehicles used for retailers, while the fourth step is used to determine the route of each vehicle to obtain optimal mileage [9]. The purpose of the "savings" method is the method used to determine the route of product distribution to the marketing area based on the capacity of the conveyance used. The goal is to obtain a proposed distribution route that is used to minimize total mileage and distribution costs. The saving matrix method is also one of the techniques used to schedule a limited number of vehicles so as to minimize distance, time, and cost by considering the existing [4]. 


\section{Methods}

\subsection{Initial Route Data and Transportation Cost}

Table 1. Initial Route Data

\begin{tabular}{clcc}
\hline No. & \multicolumn{1}{c}{ Route } & Distance Total & Request Total \\
\hline 1 & G-D27-D57-D43-D34-D45-G & 69,8 & 375 \\
\hline 2 & G-D22-D23-D28-D33-G & 38,2 & 422 \\
\hline 3 & G-D48-D19-D14-D54-G & 30,3 & 423 \\
\hline 4 & G-D21-D26-D44-G & 54,1 & 308 \\
\hline 5 & G-D35-D47-D55-G & 42,5 & 243 \\
\hline 6 & G-D11-D12-D25-D3-G & 44,7 & 357 \\
\hline 7 & G-D2-D46-D5-D41-D53-D56-G & 38,76 & 399 \\
\hline 8 & G-D32-D42-D39-G & 73,9 & 288 \\
\hline 9 & G-D9-D24-D31-G & 60,3 & 417 \\
\hline 10 & G-D1-D4-D20-D17-D13-D18-G & 52,7 & 448 \\
\hline 11 & G-D29-D40-D36-D30-G & 60 & 382 \\
\hline 12 & G-D7-D8-D37-D6-D25-G & 62,2 & 427 \\
\hline 13 & G-D10-D49-D50-D16-G & 61,6 & 318 \\
\hline 14 & G-D51-D52-D38-D15-G & 53,8 & 376
\end{tabular}

Source: PT. X

In this study, the object of research is the initial distribution route $390 \mathrm{ml}$ bottle products and the data used is secondary data in the form of data distribution companies such as information distribution area, the number of requests, type. and the amount of transportation used and transportation costs such as labor costs, fuel costs and retribution costs. From the research results $390 \mathrm{ml}$ bottle products distributed to 58 consumers by using Toyota Dyna 130 PS HT / Truck Box with 450 dozen capacity, obtained the initial route data, total demand and total distance from warehouse $(\mathrm{G})$ to consumer (D) and back to warehouse $(\mathrm{G})$ can be seen in table 1 .

Transportation costs incurred using the initial route are derived from total fuel costs, labor costs and user fees, for recapitulation and details of goods costs can be seen in Table 2 .

Table 2. Prices for transportation costs

\begin{tabular}{cll}
\hline No & \multicolumn{1}{c}{ Type of Amount } & \multicolumn{1}{c}{ Amount (IDR) } \\
1 & Bio Solar Fuel Cost & IDR 5,150,- /liters \\
2 & Levy Fees & IDR250,000,-/ trip \\
3 & Salary & IDR 500,000,- / trip \\
\hline
\end{tabular}

Source: PT. X

Transportation cost prior to application of saving matrix method on the initial route is calculated for 1 shipment of each route based on demand in May 2017.

It can be calculated the initial route transportation cost ie:

1. Fuel Costs Toyota dyna used as a means of transportation using 1 liter of bio-diesel fuel for $6 \mathrm{~km}$ distance. for fuel costs can be calculated using the following formula:

1) Fuel costs $=$ distance $\times 1 / 6 \times$ the price of diesel fuel

2) Route $1=69.8 \mathrm{~km} \times 1 / 6 \times$ IDR $5.150=$ IDR 60.031

3) Route $2=38.2 \mathrm{~km} \times 1 / 6 \times$ IDR $5.150=$ IDR 32.854 
4) Route $14=53.8 \mathrm{~km} \times 1 / 6 \times$ IDR $5.150=$ IDR 46.271 .

Thus, the total fuel cost of the initial route, is: Total cost of fuel $=$ route $1+$ route $2+$ route $3+$ route $4+$ route $5+$ route $6+$ route $7+$ route $8+$ route $9+$ route $10+$ route $11+$ route $12+$ route $13+$ route 14 Total fuel cost $=$ IDR $638,897,-/$ trip

2. Labor Cost

1) Labor Cost $=$ Number of routes $x$ Number of labor $x$ Salary

2) Labor costs $=14 \times 2 \times$ IDR 500,000 3) Labor cost $=$ IDR 14,000,000, - / month

3) Retribution Cost

Retribution cost $=$ route number $\mathrm{x}$ retribution cost Retribution fee $=14 \mathrm{x}$ IDR 250,000 Retribution fee = IDR 3,500,000, - / trip

3. Total Transportation Cost

Total transportation cost $=$ fuel cost + labor cost + retribution fee Total transportation cost $=$ IDR637,813 + IDR 14,000,000 + IDR 3,500,000 Total Transportation cost = IDR $18,137,813 .,-$ / trip.

\subsection{Identifying Distance Matrix}

This distance measurement is obtained using Google Maps app, then put it into the distance matrix table, see table 3 .

Table 3. Distance Matrix (Km)

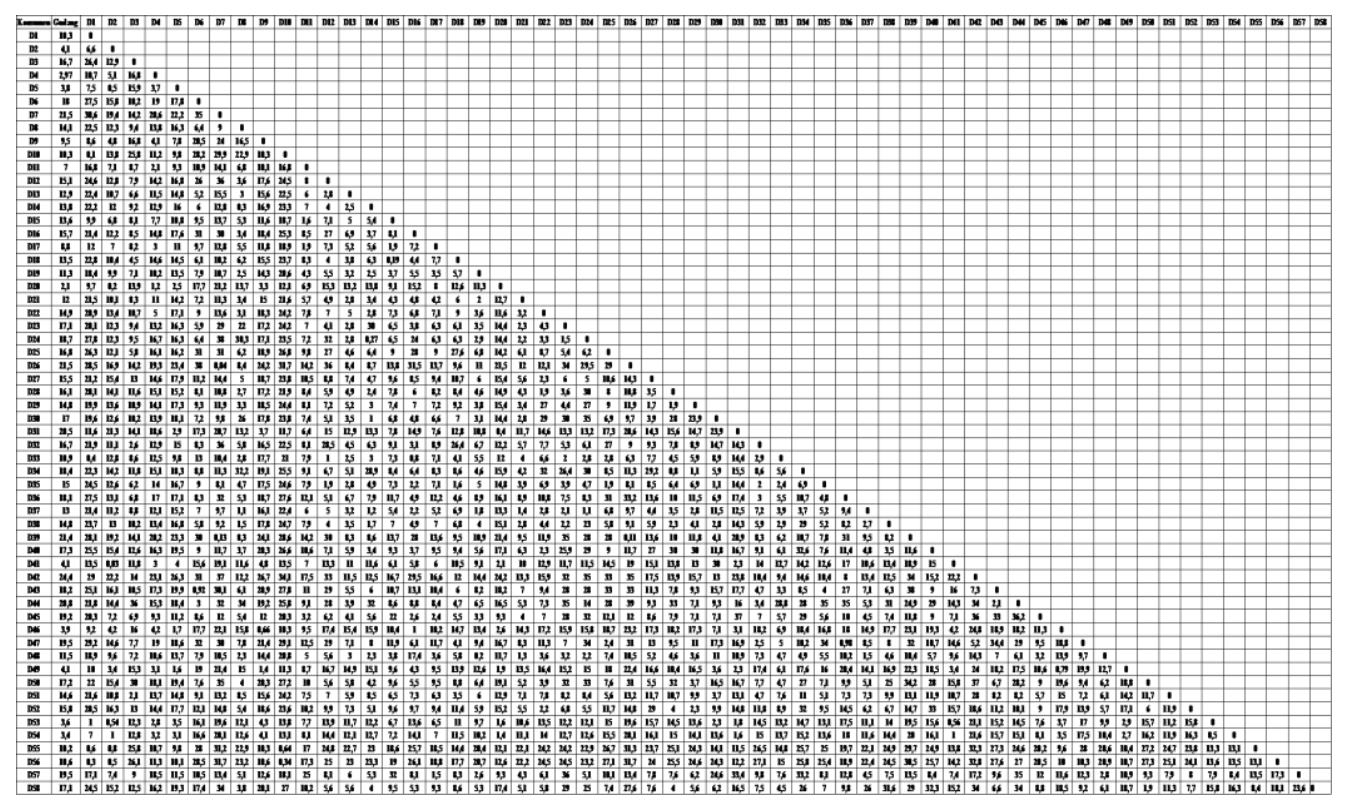

\subsection{Identifying Saving Matrix}

Identifying the savings matrix of each route can be calculated using the following formula: $\mathrm{S}(\mathrm{x}, \mathrm{y})=\mathrm{J}(\mathrm{G}, \mathrm{x})+\mathrm{J}(\mathrm{G}, \mathrm{y})-\mathrm{J}(\mathrm{x}, \mathrm{y})$ 
With the above formula can be saving matrix between consumers by using the distance in the attachment and here are some calculations in determining saving matrix:

$$
\begin{aligned}
\mathrm{S}(\mathrm{D} 1, \mathrm{D} 2) & =\mathrm{J}(\mathrm{G}, \mathrm{D} 1)+\mathrm{J}(\mathrm{G}, \mathrm{D} 2)-\mathrm{J}(\mathrm{D} 1, \mathrm{D} 2) \\
& =10,3+4,1-6,6=7,8 \\
\mathrm{~S}(57,58) & =\mathrm{J}(\mathrm{G}, 57)+\mathrm{J}(\mathrm{G}, \mathrm{D} 58)-\mathrm{J}(\mathrm{D} 57, \mathrm{D} 58) \\
& =19,5+17,1-16=20,6
\end{aligned}
$$

After obtaining the calculated value of the overall savings matrix of some consumers, the distance or value obtained is entered into the Saving Matrix table contained in table 4.

Table 4. Saving Matrix

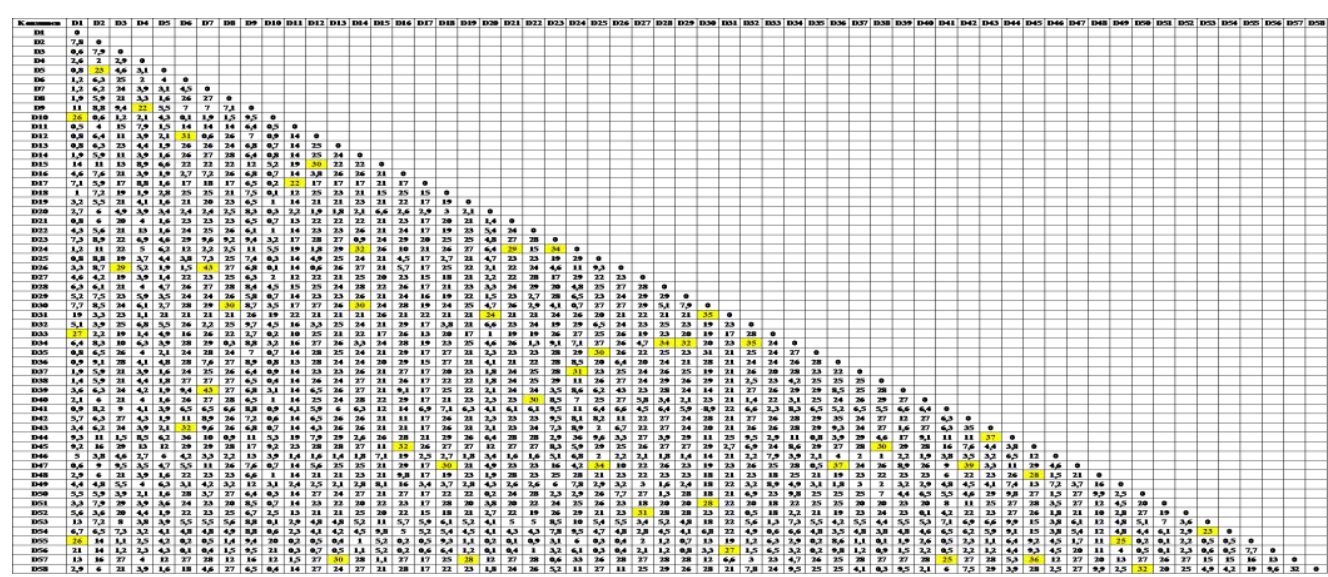

\subsection{Determining Distribution Route}

By using Saving Matrix, it can do the allocation of consumers into the route. The allocation of each different consumer can be combined with the existing truck capacity limits. Route determination starts from the largest savings value, the first largest saving value of the savings matrix table is:

- The largest savings figure is $42.96 \mathrm{~km}$ in Table 4.6 which is found in line 27 of column 8 by combining D7 and D26, with the sum of requests D7 $=98$ dozen and D26 $=100$ dozen then combined $98+100=198$ dozen ( $<450$ dozen / capacity truck). Because D26 is closer to the warehouse than the D7 then route 1: G-D26-D7.

From the search and consumer allocation above then got the proposed route by using saving matrix method that is 12 routes and can be seen in table 5 .

Table 5. Proposed Route

\begin{tabular}{clcc}
\hline No. & \multicolumn{1}{c}{ Proposed route } & Distance $(\mathrm{km})$ & $\begin{array}{c}\text { Truck capasity } \\
\text { (dozen) }\end{array}$ \\
\hline 1 & G-D26-D7-D39-D47-D42-G & 35,67 & 450 \\
\hline 2 & G-D44-D43-D36-D45-D57-G & 56,9 & 450 \\
\hline 3 & G-D30-D31-D34-D32-G & 60,1 & 445 \\
\hline 4 & G-D23-D24-D28-G & 37,4 & 450 \\
\hline 5 & G-D50-D58-D16-D6-D29-G & 51 & 448 \\
\hline 6 & G-D27-D52-D37-D12-D15-G & 48 & 450 \\
\hline 7 & G-D25-D35-D22-D40-D8-G & 48,9 & 450 \\
\hline 8 & G-D14-D13-D18-D38-G & 41,4 & 440 \\
\hline 9 & G-D46-D56-D48-D19-D51-D21-D3-G & 56,3 & 381 \\
\hline
\end{tabular}




\begin{tabular}{clcc}
\hline 10 & G-D1-D33-D10-D55-D49-D41-D20-G & 29,74 & 439 \\
\hline 11 & G-D2-D5-D54-D53-G & 27,87 & 437 \\
\hline 12 & G-D4-D9-D11-D17-G & 11,8 & 388 \\
\hline
\end{tabular}

\subsection{TransportationCost Estimation}

1. Fuel Costs

Fuel cost $=$ distance $\times 1 / 6 \times$ the price of diesel fuel Route $1=35.67 \mathrm{~km} \times 1 / 6 \times$ IDR 5.150 $=$ IDR 30.678 Route $12=11.8 \mathrm{~km} \times 1 / 6 \times$ IDR $5.150=$ IDR 10.148 So, the total fuel cost of the proposed route, is: Total cost of fuel $=$ route $1+$ route $2+$ route $3+$ route $4+$ route $5+$ route $6+$ route $7+$ route $8+$ route $9+$ route $10+$ route $11+$ route 12 ) Total fuel cost $=$ IDR 434.394,-/ trip

2. Labor costs

Labor cost $=$ Number of routes $\mathrm{x}$ Number of labor $\mathrm{x}$ payroll Labor cost $=12 \mathrm{x} 2 \mathrm{x}$ IDR 500,000 Labor cost = IDR 12.000.000,-/ trip

3. Retribution Fees

Retribution fees $=$ route number $\mathrm{x}$ retribution cost Retribution fee $=12 \times$ IDR 250,000 Retribution fee $=$ IDR 3.000.000, - / month

4. Transportation Total Cost Total transportation cost $=$ fuel cost + labor cost + retribution cost Total transportation cost $=$ IDR 434,394 + IDR 12,000,000+ IDR 3,000,000.

5. Total transportation cost $=$ IDR $15.434 .394,-/$ trip.

\section{Results and Discussion}

\subsection{Efficiency of Distance}

Comparison of the initial distribution route run by the company with the proposed route done by using saving matrix method can be seen in Table 6 below.

Table 6. Comparison of Initial Routes and ProposedRoutes

\begin{tabular}{|c|c|c|c|c|c|c|}
\hline \multicolumn{4}{|c|}{ Initial Route } & \multicolumn{3}{|c|}{ Proposed Route } \\
\hline No & Route & Distance Total & Request Total & Proposed route & Distance (km) & $\begin{array}{c}\text { Truck capasity } \\
\text { (dozen) }\end{array}$ \\
\hline 1 & -D57-D43-D34- & 69,8 & 375 & 6-D7-D39-D47-D & 35,67 & 450 \\
\hline 2 & 22-D23-D28-D3 & 38,2 & 422 & |-D43-D36-D45-I & 56,9 & 450 \\
\hline 3 & 48-D 19-D 14-D5 & 30,3 & 423 & 30-D31-D34-D3 & 60,1 & 445 \\
\hline 4 & -D21-D26-D44- & 54,1 & 308 & i-D23-D24-D28-1 & 37,4 & 450 \\
\hline 5 & -D35-D47-D55- & 42,5 & 243 & D-D58-D16-D6-D & 51 & 448 \\
\hline 6 & $11-\mathrm{D} 12-\mathrm{D} 25-\mathrm{D}$ & 44,7 & 357 & '-D52-D37-D12-I & 48 & 450 \\
\hline 7 & 46-D5-D41-D53 & 38,76 & 399 & 5-D35-D22-D40- & 48,9 & 450 \\
\hline 8 & -D32-D42-D39- & 73,9 & 288 & 14-D13-D18-D3 & 41,4 & 440 \\
\hline 9 & i-D9-D24-D31-c & 60,3 & 417 & 6-D48-D19-D51- & 56,3 & 381 \\
\hline 10 & 4-D20-D17-D 13 & 52,7 & 448 & -D10-D55-D49-D & 29,74 & 439 \\
\hline 11 & 29-D40-D36-D3 & 60 & 382 & D2-D5-D54-D53 & 27,87 & 437 \\
\hline 12 & 7-D8-D37-D6-D & 62,2 & 427 & D4-D9-D11-D17 & 11,8 & 388 \\
\hline 13 & 10-D49-D50-D 1 & 61,6 & 318 & & & \\
\hline 14 & 51-D52-D38-D 1 & 53,8 & 376 & & & \\
\hline
\end{tabular}


From table 6 it can be seen that the proposed route has a total shorter distance compared to the route used by the company, that is on the total proposed route traveled by $505.08 \mathrm{~km}$ and on the initial route the total distance traveled by $742.86 \mathrm{~km}$ with the difference between the proposed route and the initial route of $237.78 \mathrm{~km}$ can be calculated the efficiency of distance by:

Distance fisiensi $=\frac{\text { initial route }- \text { proposed route }}{\text { initial route }} \times 100 \%$

Then the efficiency of distance obtained using saving matrix method is as follows:

$$
\text { Distance Efisiensi }=\frac{742,86-505,08}{742,86} \times 100 \%=0,32 \times 100 \%=32 \%
$$

From the above calculation efficiency of distance of $32 \%$ of the distance used by the company.

\subsection{Transportation cost Efficiency}

The comparison of the initial transportation cost incurred by the company with the cost of transporting the proposals obtained using the saving matrix method can be seen in Table 7 below:

Table 7. Comparision Transportation Cost

\begin{tabular}{cllrll}
\hline & \multicolumn{2}{c}{ Initial Route } & \multicolumn{2}{c}{ Proposed Route } \\
\hline No & \multicolumn{1}{c}{ Cost Type } & Ammount (IDR) & No & Cost Type & $\begin{array}{l}\text { Ammount } \\
\text { (IDR) }\end{array}$ \\
\hline 1 & Fuel cost & IDR 63,897 & 1 & Fuell cost & IDR 434,394 \\
\hline 2 & Labour coat & IDR 14,000,000 & 2 & Labour cost & IDR 12,000,000 \\
\hline 3 & Retribution fee & IDR 3,500,000 & 3 & Retribution fee & IDR 3,000,000 \\
\hline Total & & IDR 18,138,897 & \multicolumn{2}{c}{ Total } & IDR 15,434,394 \\
\hline
\end{tabular}

From table 7 it can be seen that the transportation cost before the implementation of the saving matrix method of the company incur a transportation cost of IDR 18,138,897, - / trip while using the saving matrix method of transportation cost generated is IDR 15.434.394 / trip to obtain transportation cost savings for IDR 2,704,503 / - trip. By using transportation cost of proposal then can efficiency of transportation cost can be calculated by:

Cost Efficiency

$$
\begin{aligned}
& =\frac{\text { initial cost }- \text { proposed cost }}{\text { initial cost }} \times 100 \% \\
& =\frac{\mathbf{1 8 1 3 8 8 9 7 - \mathbf { 1 5 4 3 4 3 9 4 }}}{\mathbf{1 8 1 3 8 8 9 7}} \times \mathbf{1 0 0} \% \\
& =\mathbf{0}, \mathbf{1 4 9} \times \mathbf{1 0 0} \%=\mathbf{1 4 , 9} \%
\end{aligned}
$$

From the above calculation cost efficiency of $14.9 \%$ of transportation costs incurred by the company. 


\section{Conclusions}

Based on the Processing, analysis and discussion conducted in this study, it can be drawn some conclusions, namely:

1. The formation of the proposed route using saving matrix method resulted in lower total mileage compared to the total mileage applied by the company, where the number of routes applied by the company there are 14 routes with a total distance of $742.86 \mathrm{~km}$, while the proposed route produces 12 routes with a total distance of $505.08 \mathrm{~km}$ and efficiency of $32 \%$ of the total initial route used by the company, with the distribution of products to 58 consumers in Medan company still use the truck where each truck changes the route taken, the distance is different from the previous route and the capacity corresponding.

2. Using the proposed route obtained from data processing using saving matrix method can save total transportation cost, where total transportation cost on the initial route is IDR 18.138.897, - / trip and total transportation cost after application of saving matrix method on the proposed route of IDR 15,434,394. - / journey so as to obtain transportation cost savings of IDR $2,704,503$. - / travel and efficiency of $14.9 \%$ of transportation costs used in the company.

\section{References}

[1] Rahmi, Meliza. 2016. Penentuan Rute Distribusi Sirup Untuk Meminimalkan Biaya Transportasi (Studi Kasus: CV. Nira Della 38). Lhokseumawe: Jurusan Teknik Industri Universitas Malikussaleh

[2] Lubis, Arlina Nurbaity, 2004, Peranan Saluran Distribusi Dalam Pemasaran Produk Dan Jasa, http:/digilib.usu.ac.id/download/fe/manajemenarlina\%20lbs4.pdf, diakses pada 12 Februari 2017.

[3] Chandra Robert. 2013. Rancang Bangun Aplikasi Penentuan Rute Dan Penjadwalan Distribusi Barang Dengan Metode Clarke - Wringht Saving Heuristic. Surabaya: Jurusan Sistem Informasi STIKOM Surabaya.

[4] Rahmawati, Ririn. (2013). Usulan Model Dalam Menentukan Rute Distribusi Untuk Meminimalkan Biaya Transportasi Dengan Metode Saving Matrix Di PT. Siantar Top, TBK. Medan: Jurusan Teknik Industri Universitas Sumatra Utara.

[5] Ikfan, Noer dan Iiyas Masudin. (2014). Saving Matrix untuk menentukan Rute Distribusi - Jurnal Ilmiah Teknik Industri. Diambil dari Jurnal Ilmiah Universitas Muhammadiyah Malang.

[6] Sextovianto, Rizal. 2010. Peningkatan Efisiensi Pendistribsian Koran Dengan Menentukan Jalur Distribusi Paling Optimal dengan mengunakan Metode Saving Matrix Di Pt. Harian Surabaya Pagi. Surabaya: Jurusan Teknik Industri ITS.

[7] Setia,Budhi.2007.http://elib.unikom.ac.id/files/disk 1/116/jbptunikompp-gdl-s1-2007-budhisetia5763-b ab-ii.pdf

[8] Taha, Hamdy A dan Saputra L. (2008). Riset Operasi Jilid Satu, Binarupa Aksara, Jakarta.

[9] Effendi Ahmad,dkk. 2013. Penentuan Rute Optimal Distribusi Produk Dengan Metode Saving Matrix Dan Traveling Salesman Problem Di PT. Romindo Prima Vetcom. Jatim: Jurusan Teknik Industri FTI-UPN. 